\title{
Dotacje udzielane przez jednostki samorządu terytorialnego niepublicznym podmiotom prowadzącym szkoły i placówki oświatowe
}

\section{Local government grants for private schools}

Streszczenie. W artykule zostały poddane analizie zagadnienia prawne dotyczące dotacji udzielanych przez jednostki samorządu terytorialnego podmiotom prowadzącym niepubliczne szkoły i placówki oświatowe. Autorka przedstawiła procedury zakładania niepublicznych szkół i placówek oświatowych, przedstawiła konstrukcję dotacji oświatowej, wyjaśniła wybrane pojęcia i zagadnienia dotyczące jednostek oświaty oraz zaprezentowała orzecznictwo w sprawach o dotacje. W artykule zaprezentowano wybrane orzeczenia SN i NSA w sporach o dotacje.

Słowa kluczowe: dotacje oświatowe z budżetu jednostki samorządu terytorialnego; niepubliczne szkoły i placówki oświatowe; właściwość sądów w sporach o dotacje oświatowe.

Abstract. This article aims to analyze the educational grants from budget of local government. Author presented procedures about establish private schools and 
educational institutions and explained selected concepts about units of education. The article presents selected judgment from SN and NSA in disputes about grants for private schools.

Keywords: educational grants from the budget of local government, private schools and educational institutions, jurisdiction in matters of educational grants.

\section{Uwagi wstępne. Cel opracowania}

Według art. 70 Konstytucji RP zadania z zakresu edukacji są zadaniami publicznymi $^{1}$. Zadaniem publicznym określa się zadanie wywodzące się z Konstytucji i obowiązujących ustaw, które służy zaspokajaniu potrzeb zbiorowych, jest ono przypisane państwu oraz szeroko rozumianym podmiotom władzy publicznej, które ponoszą w świetle prawa odpowiedzialność za jego zrealizowanie ${ }^{2}$.

Zadania oświatowe zostały nałożone na jednostki samorządu terytorialnego zgodnie z przyjętymi, podstawowymi zasadami podziału zadań publicznych - zasadą pomocniczości oraz zasadą decentralizacji. Zasady pomocniczości i decentralizacji należą do najważniejszych zasad określających podział zadań publicznych na różne podmioty, są one zawarte w art. 16 ust. 2 oraz art. 15 ust. 1 Konstytucji ${ }^{3}$.

W jednym z orzeczeń NSA wyrażone jest stanowisko, że odpowiedzialność państwa lub podmiotów władzy publicznej za realizację zadań publicznych stanowi podstawowe kryterium dla uznania danych zadań za publiczne, jednakże samo wykonanie zadań publicznych nie musi odbywać się w strukturach organizacyjnych państwa lub samorządu terytorialnego (wyrok NSA z dnia 28 stycznia 2014 r., I OSK 2076/13).

Zadania publiczne mogą więc wykonywać zarówno podmioty publiczne, jak i podmioty spoza sektora publicznego. Realizacja zadań publicznych przez podmioty spoza sektora finansów publicznych ma odcią-

Konstytucja RP z dnia 2 kwietnia 1997 r. (Dz.U. Nr 78, poz. 483).

Por. wyrok NSA z dnia 28 stycznia 2014 r. I OSK 2076/13.

D. Kurzyna-Chmiel, Oświata jako zadanie publiczne, Warszawa 2013, s. 124 i 129. 
żyć administrację oraz zapewnić lepsze zaspokojenie potrzeb zbiorowych i ochronę jednostki ${ }^{4}$.

Zadania z zakresu edukacji publicznej należą do zadań własnych gminy, o czym stanowi art. 7 ust. 1 pkt 8 ustawy o samorządzie gminnym $^{5}$. Powiat wykonuje kreślone ustawami zadania publiczne o charakterze ponadgminnym w tym zadania w zakresie edukacji publicznej (art. 4 ust. 1 pkt 4 ustawy o samorządzie powiatowym) ${ }^{6}$. Do zadań samorządu województwa należy wykonywania zadań o charakterze wojewódzkim (o znaczeniu regionalnym lub ponadregionalnym) w szczególności w zakresie edukacji publicznej, w tym szkolnictwa wyższego (art. 14 ust. 1 pkt 1 ustawy o samorządzie województwa) ${ }^{7}$.

Szkolnictwo może przybierać postać szkolnictwa publicznego i niepublicznego, co wynika z art. 70 ust. 3 Konstytucji. Przepis art. 70 Konstytucji gwarantuje prawo do nauki, prawo rodziców do wyboru dla ich dzieci szkół innych niż publiczne, prawo obywateli i instytucji do zakładania szkół podstawowych, ponadpodstawowych i wyższych. Postanawia też, że warunki zakładania i działalności szkół niepublicznych, ich finansowanie z udziałem władz publicznych, a także zasady nadzoru pedagogicznego nad tymi szkołami określa ustawa. Ustawą tą jest wielokrotnie nowelizowana ustawa z dnia 7 września 1991 r. o systemie oświaty ${ }^{8}$.

Opracowanie niniejsze koncentruje się na problematyce finansowania oświaty niepublicznej. Zadania oświatowe realizowane przez podmioty niepubliczne mogą być finansowane ze środków publicznych. Z tego względu zagadnienie to ciągle pozostaje w zakresie zainteresowań ekonomistów, prawników czy samorządowców. Celem opracowania jest przedstawienie zadania oświatowego, jakim jest zakładanie i prowadzenie szkół i placówek oświatowych, które realizowane jest przez podmioty

Tamże, s. 138.

Ustawa z dnia 8 marca 1990 r. o samorządzie gminnym (tekst jedn. Dz.U. z 2015 r., poz. 1515).

6 Ustawa z dnia 5 czerwca 1998 r. o samorządzie powiatowym (tekst jedn. Dz.U. z 2015 r., poz. 1445).

7 Ustawa z dnia 5 czerwca 1998 r. o samorządzie województwa (tekst jedn. Dz.U. z 2015 r., poz. 1392).

8 Ustawa z dnia 7 września 1991 r. o systemie oświaty (tekst jedn. Dz.U. z 2015 r., poz. 2156, dalej u.s.o.). 
spoza sektora finansów publicznych.

Zagadnienia analizowane $\mathrm{w}$ artykule to: regulacje prawne zawarte w ustawie o systemie oświaty, które zezwalają podmiotom prywatnym świadczyć usługi w zakresie oświaty i wychowania; przedstawienie procedur zakładania i prowadzenia szkół i placówek oświatowych przez podmioty prywatne; wyjaśnienie wybranych pojęć i zagadnień dotyczących jednostek oświaty; scharakteryzowanie dotacji udzielanej szkołom i placówkom niepublicznym; analiza procedur związanych z uchwałą jednostek samorządu terytorialnego dotyczącą dotacji dla szkół niepublicznych oraz zaprezentowanie orzecznictwa w sprawach o dotacje.

\section{Wybrane instytucje systemu oświaty}

Ustawa o systemie oświaty w art. 5 stanowi, że szkoła i placówka może być szkołą i placówką publiczną albo niepubliczną. Szkoły i placówki publiczne spełniają warunki zawarte w art. 7 ustawy o systemie oświaty. Przede wszystkim szkoły i placówki publiczne zapewniają bezpłatne nauczanie w zakresie ramowych planów nauczania i przeprowadzają rekrutację uczniów w oparciu o zasadę powszechnej dostępności. Bezpłatność nauczania oraz powszechna dostępność szkół publicznych pozwala na odróżnienie ich od szkół niepublicznych. Szkoły niepubliczne, które są tworzone w interesie węższej grupy osób, a nie ogółu, charakteryzuje brak wymagania zapewnienia powszechnej dostępności oraz brak ustawowej gwarancji bezpłatności kształcenia, wychowania i opieki. Szkołą i placówką niepubliczną jest każda szkoła lub placówka, która nie jest „publiczna” w rozumieniu art. 7 ust. 1 u.s.o. ${ }^{9}$

Podmioty zakładające i prowadzące szkoły i placówki to wymienione w art. 5 ust. 2 u.s.o. jednostki samorządu terytorialnego, inne osoby prawne i osoby fizyczne.

Podstawowym zadaniem oświatowym jednostek samorządu terytorialnego jest zakładanie i prowadzenie szkół i placówek oświatowych. Regulacje dotyczące zakładania i prowadzenia poszczególnych typów

$9 \quad$ M. Pilich, Komentarz do ustawy o systemie oświaty, Warszawa 2015, s. 1224. 
i rodzajów szkół i placówek przez j.s.t. zawiera art. 5 u.s.o. Zakładanie i prowadzenie szkół i placówek wymienionych w art. 5 u.s.o. należy do zadań własnych gminy lub powiatu.

Ustawa o systemie oświaty w art. 5 ust. 3 i 3a stanowi, że osoby prawne prawa publicznego, takie jak np. j.s.t., mogą zakładać i prowadzić tylko szkoły i placówki publiczne. Natomiast podmioty prowadzące szkołę lub placówkę niepubliczną muszą być osobami fizycznymi lub powinny spełniać warunek posiadania osobowości prawnej. Chodzi więc o następujące typy podmiotów: osoby fizyczne, stowarzyszenia, fundacje oraz spółki kapitałowe prawa handlowego ${ }^{10}$.

Ustawa o systemie oświaty reguluje sprawę typów szkół. Art. 9 ustawy dokonuje podziału szkół publicznych i niepublicznych na: 6-letnią szkołę podstawową, 3-letnie gimnazjum oraz szkoły ponadgimnazjalne. W ramach kategorii tych ostatnich można wyróżnić następujące „podtypy”: 3-letnią zasadniczą szkołę zawodową, 3-letnie liceum ogólnokształcące, szkołę policealną oraz 3-letnią szkołę specjalną przysposabiającą do pracy. Zatem określenie „typ szkoły” wskazuje na etap kształcenia, a w przypadku tzw. podtypów szkół ponadgimnazjalnych wskazują też na bliższą charakterystykę tego kształcenia ${ }^{11}$.

Art. 2 ustawy o systemie oświaty stanowi o tym, jakie przedszkola, szkoły i placówki obejmuje system oświaty. Według art. 2 pkt 2 system oświaty obejmuje: a) szkoły podstawowe, w tym: specjalne, integracyjne, z oddziałami integracyjnymi i sportowymi, sportowe i mistrzostwa sportowego, b) gimnazja, w tym: specjalne, integracyjne, dwujęzyczne, z oddziałami integracyjnymi, dwujęzycznymi, sportowymi przysposabiającymi do pracy, sportowe i mistrzostwa sportowego; c) ponadgimnazjalne, w tym: specjalne, integracyjne, dwujęzyczne, z oddziałami integracyjnymi, dwujęzycznymi i sportowymi, sportowe, mistrzostwa sportowego, rolnicze i leśne; d) artystyczne.

Szkoły i placówki mogą być szkołami i placówkami publicznymi prowadzonymi przez j.s.t. oraz ministrów (czyli podmioty z sektora finansów publicznych), szkoły i placówki mogą być też niepubliczne, są one

$10 \quad$ Tamże, s. 78.

11 Tamże, s. 177. 
zakładane i prowadzone przez podmioty spoza sektora finansów publicznych. Ustawa o systemie oświaty w art. 8 stanowi, że szkoła podstawowa i gimnazjum może być tylko szkołą publiczną lub niepubliczną o uprawnieniach szkoły publicznej.

Szkoła niepubliczna może uzyskać uprawnienia szkoły publicznej, jeżeli spełnia warunki zawarte w art. 7 ust. 3 ustawy o systemie oświaty. Są one następujące: realizacja programów nauczania uwzględniających podstawy programowe kształcenia ogólnego; realizacja zajęć edukacyjnych w cyklu nie krótszym oraz w wymiarze nie niższym niż łączny wymiar obowiązkowych zajęć edukacyjnych określonych w ramowym planie nauczania szkoły publicznej danego typu; stosowanie zasad klasyfikowania i promowania uczniów oraz przeprowadzania sprawdzianu i egzaminów, o których mowa w ust. 1 pkt 5; prowadzenie dokumentacji przebiegu nauczania ustalonej dla szkół publicznych oraz zatrudnianie nauczycieli obowiązkowych zajęć edukacyjnych, o których mowa w pkt 2, posiadających kwalifikacje określone dla nauczycieli szkół publicznych (art. 7 ust. 3 u.s.o.). Ponadto szkoła niepubliczna o uprawnieniach szkoły publicznej zgodnie z art. 7 ust. 2 u.s.o. umożliwia uzyskanie świadectw lub dyplomów państwowych. Niepublicznej szkole podstawowej, niepublicznemu gimnazjum i niepublicznej szkole artystycznej realizującej kształcenie ogólne w zakresie szkoły podstawowej lub gimnazjum, założonym zgodnie z art. 82 ust. 1-3, przysługują uprawnienia szkoły publicznej z dniem rozpoczęcia działalności (art. 85 ust. 1 u.s.o.).

Podnosi się, iż tworzenie przez podmioty niepubliczne szkół i placówek o uprawnieniach szkół publicznych jest niekonsekwencją polskiej regulacji ustroju szkolnego. Szkoły te są własnością prywatną, natomiast formalnie (z punktu widzenia administracyjnoprawnego) mają status analogiczny do szkół prowadzonych przez samorząd terytorialny i państwo ${ }^{12}$.

12 Tamże, s. 982. 


\section{Procedury zakładania szkół i placówek niepublicznych}

Ustawa o systemie oświaty reguluje procedury zakładania i prowadzenia niepublicznych szkół i placówek przez osoby fizyczne i osoby prawne. Według art. 82 ust. 1 ustawy o systemie oświaty w przypadku zakładania szkoły i placówki niepublicznej, przez osoby fizyczne i osoby prawne, osoby te muszą uzyskać jedynie wpis do ewidencji. Ewidencję szkół i placówek niepublicznych prowadzi jednostka samorządu terytorialnego obowiązana do prowadzenia odpowiedniego typu publicznych szkół i placówek (art. 82 ust. 1 u.s.o.). Zgodnie z art. 5 ustawy o systemie oświaty do właściwości gminy należy prowadzenie ewidencji niepublicznych przedszkoli, w tym integracyjnych oraz specjalnych, szkół podstawowych z wyjątkiem specjalnych oraz gimnazjów - z wyjątkiem specjalnych. Zadaniem powiatu według art. 5a ustawy o systemie oświaty jest prowadzenie ewidencji szkół podstawowych specjalnych i gimnazjów specjalnych oraz pozostałych szkół i placówek wymienionych w tym artykule.

Art. 82 w ust. 2 u.s.o. zawiera regulacje dotyczące zgłoszenia do ewidencji, które powinno zawierać oznaczenie osoby zamierzającej prowadzić szkołę lub placówkę, jej miejsce zamieszkania lub siedziby; określenie odpowiednio typu i rodzaju szkoły lub placówki oraz daty rozpoczęcia jej funkcjonowania, a także wskazanie miejsca prowadzenia szkoły lub placówki oraz informację o warunkach lokalowych (szczegółowo wymienionych w ust. 2 pkt 3 lit a, b, c i d omawianego artykułu). Do zgłoszenia należy dołączyć statut szkoły lub placówki, dane dotyczące kwalifikacji pracowników pedagogicznych i dyrektora, przewidzianych do zatrudnienia w szkole lub placówce oraz dane niezbędne do wpisania szkoły lub placówki do krajowego rejestru urzędowego podmiotów gospodarki narodowej. Wpis do ewidencji „organ ewidencyjny” dokonuje w ciągu 30 dni od daty zgłoszenia. Wydaje zaświadczenie o wpisie do ewidencji, którego kopię z urzędu doręcza zgłaszającemu oraz m.in. właściwemu kuratorowi oświaty (art. 82 ust. 3 u.s.o.). W przypadku odmowy wpisu do ewidencji ten sam „organ ewidencyjny” wydaję decyzję administracyjną o odmowie wpisu (art. 82 ust. 4 u.s.o.). 
Podmioty niepubliczne chcące założyć szkołę o uprawnieniach szkoły publicznej do wniosku o wpis do ewidencji muszą dołączyć zobowiązanie do przestrzegania wymagań określonych w art. 7 ust. 3 u.s.o. oraz zgodnie z art. 82 ust. 2a u.s.o. muszą przedstawić pozytywną opinię kuratora oświaty.

Zgodnie z art. 85 ust. 2 u.s.o. w podstawowych szkołach niepublicznych i niepublicznych gimnazjach, które uzyskały uprawnienia szkoły publicznej z dniem rozpoczęcia działalności, zobowiązanym do sprawdzenia, czy zostały spełnione warunki określone w art. 7 ust. 3, jest kurator oświaty. Termin na przeprowadzenie kontroli w tej sprawie wynosi 6 miesięcy od dnia rozpoczęcia działalności opisanych wyżej szkół i placówek.

Inny tryb powstania szkół, przedszkoli, innych form wychowania przedszkolnego oraz placówek publicznych prowadzonych przez podmioty niepubliczne określa art. 5 ust. $5 g$ u.s.o. Przepis ten umożliwia przekazanie szkoły, której organem prowadzącym jest j.s.t., do prowadzenia podmiotowi spoza sektora finansów publicznych. Aby mogło dojść do przekazania szkoły, muszą zostać spełnione warunki: szkoła nie może liczyć więcej niż 70 uczniów oraz należy uzyskać pozytywną opinię organu sprawującego nadzór pedagogiczny.

Zgodnie z art. 5 ust. 5 u.s.o. jednostka samorządu terytorialnego, będąca organem prowadzącym szkołę, przedszkole lub placówkę liczącą nie więcej niż 70 uczniów, na podstawie uchwały organu stanowiącego tej jednostki oraz po uzyskaniu pozytywnej opinii organu sprawującego nadzór pedagogiczny, może przekazać w drodze umowy osobie fizycznej lub osobie prawnej innej niż j.s.t. prowadzenie takiej szkoły, przedszkola lub placówki.

\section{Dotacje dla podmiotów niepublicznych prowadzących szkoły i placówki oświatowe}

Głównym źródłem finansowania zadań oświatowych realizowanych przez j.s.t. jest subwencja oświatowa. Jest ona elementem systemu dochodów jednostek samorządu terytorialnego. Subwencja oświatowa jest częścią subwencji ogólnej, stanowi główne źródło finansowania oświaty przez 
samorządy ${ }^{13}$. Subwencja jest kierowana głównie na finansowanie wydatków bieżących szkół i placówek prowadzonych przez j.s.t., a także dotowanie szkół i placówek publicznych oraz niepublicznych prowadzonych przez podmioty spoza sektora finansów publicznych ${ }^{14}$.

Termin „dotacja” służy określeniu wszelkich świadczeń dokonywanych z budżetu podmiotu publicznego na rzecz osób trzecich na podstawie norm prawa budżetowego lub odrębnych materialno-prawnych norm prawa finansowego w trybie władczym ${ }^{15}$.

Zgodnie z art. 126 ustawy o finansach publicznych dotacje to podlegające szczególnym zasadom rozliczania środki z budżetu państwa, budżetu jednostek samorządu terytorialnego oraz z państwowych funduszy celowych przeznaczone na podstawie tej ustawy, odrębnych ustaw lub umów międzynarodowych, na finansowanie lub dofinansowanie zadań publicznych $^{16}$.

Według A. Ostrowskiej udzielanie dotacji podmiotom nienależącym do sektora finansów publicznych i dotowanie z budżetów j.s.t. zadań realizowanych przez te podmioty, należy uznać za przejaw decentralizacji finansów publicznych, jest to dalszy etap tej decentralizacji ${ }^{17}$.

Niepubliczne oraz publiczne szkoły i placówki oświatowe prowadzone przez osoby fizyczne i osoby prawne inne niż j.s.t. są dotowane z budżetu poszczególnych jednostek samorządowych. O dotacjach tych mówi art. 90 ustawy o systemie oświaty.

Zadania z zakresu edukacji realizowane przez podmioty spoza obszaru administracji publicznej należy traktować jako zadania publiczne, co przesądza o tym, że dotacje otrzymywane przez niepubliczne szkoły są dotacjami, o których mowa w art. 126 ustawy o finansach publicznych (por. wyrok NSA z dnia 28 stycznia 2014 r., I OSK 2076/13). Szkoły niepubliczne dysponują zatem majątkiem publicznym w postaci dotacji, a w odniesieniu do środków

\footnotetext{
A. Borodo, Samorzqd terytorialny. System prawnofinansowy, Warszawa 2012, s. 110. Tamże, s. 111.

Z. Ofiarski, Subwencje i dotacje jednostek samorzqdu terytorialnego, Warszawa 2002, s. 26. Ustawa z dnia 27 sierpnia 2009 r. o finansach publicznych (Dz.U. z 2013 r., poz. 885 ze zm.). A. Ostrowska, Udzielanie dotacji niepublicznym jednostkom oświaty - samorzq̨dowa powinność czy samorzqdowe władztwo finansowe? [w:] A. Borodo (red.), Dotacje i subwencje w systemie finansowym samorzqdu terytorialnego, Toruń 2013, s. 186.
} 
publicznych muszą obowiązywać szczególne zasady weryfikacji ich wydatkowania, zwłaszcza jeżeli środki te wydatkowane są przez podmioty niepubliczne (wyrok NSA z dnia 9 stycznia 2014 r., II GSK 1570/12).

Ustawa o finansach publicznych wymienia dotacje: celowe, przedmiotowe i podmiotowe. Dotacje dla niepublicznych szkół i placówek prowadzonych przez osoby fizyczne i osoby prawne inne niż j.s.t. mają charakter dotacji podmiotowych, służą bowiem finansowaniu bieżącej działalności tych jednostek oświatowych. Jednak dodanie nowych regulacji ustawowych w 2009 r. (w ustawie o systemie oświaty), które umożliwiły organom stanowiącym j.s.t. podstawę do szczegółowego uregulowania w swych uchwałach trybu i zakresu kontroli prawidłowości wykorzystania dotacji, spowodowały, iż omawiane dotacje można obecnie uznać za dotacje o charakterze mieszanym, podmiotowo-celowym ${ }^{18}$.

Dotacje podmiotowe zgodnie z art. 131 ustawy o finansach publicznych obejmują środki dla podmiotu wskazanego w odrębnej ustawie lub w umowie międzynarodowej, wyłącznie na dofinansowanie działalności bieżącej w zakresie określonym w odrębnej ustawie lub umowie międzynarodowej. Odrębną ustawę należy definiować zgodnie z art. 2 ustawy o finansach publicznych - jako inną niż ustawa o finansach publicznych oraz ustawa budżetowa. Z przepisu u.f.p. dotyczącego dotacji podmiotowej wynika, że może być ona przeznaczona tylko na dofinansowanie działalności bieżącej. Dotacja podmiotowa nie może być wykorzystana na finansowanie wydatków inwestycyjnych ${ }^{19}$.

Podmiotami otrzymującymi dotacje podmiotowe, wskazanymi w odrębnej ustawie, są m.in. podmioty wskazane w ustawie o systemie oświaty. Są to podmioty spoza sektora finansów publicznych uprawnione do zakładania i prowadzenia niepublicznych szkół i placówek oświatowych, a działalnością bieżącą, o której mowa art. 131 ustawy o finansach publicznych, jest działalność opisana w art. 90 ust. 3d oraz w art. 80 ust. 3d u.s.o. Działalność ta obejmuje prowadzenie szkoły, przedszkola, innej

Tamże, s. 190.

19 A. Ostrowska, Jakie sq istota i rodzaje dotacji podmiotowych udzielanych z budżetu j.s.t.? [w:] C. Kosikowski, J.M. Salachna (red.), Finanse samorzq̨dowe. 580 pytań i odpowiedzi, Warszawa 2012, s. 331. 
formy wychowania przedszkolnego lub placówki przez osobę fizyczną, jeżeli osoba ta odpowiednio pełni funkcję dyrektora szkoły, przedszkola lub placówki albo prowadzi zajęcia w innej formie wychowania przedszkolnego oraz realizację zadań organu prowadzącego, o których mowa w art. 5 ust. 7 ustawy o systemie oświaty.

Dotacja dla niepublicznych szkół i placówek oświatowych ma charakter podmiotowo-celowy, ponieważ art. 90 ust. 3d określa cel, na który dotacja ta ma być wydatkowana. Zgodnie bowiem z tym przepisem dotacje są przeznaczane na dofinansowanie realizacji zadań szkoły, przedszkola, innej formy wychowania przedszkolnego lub placówki w zakresie kształcenia, wychowania i opieki, w tym profilaktyki społecznej ${ }^{20}$. W niektórych orzeczeniach NSA również przyjmuje się, że jest to dotacja o charakterze mieszanym (podmiotowo-celowa) ${ }^{21}$.

Dotacja dla niepublicznych szkół i placówek prowadzonych przez osoby fizyczne i osoby prawne, udzielana jest pod warunkiem, że osoba prowadząca odpowiednio szkołę, przedszkole i inną placówkę oświatową poda organowi właściwemu do udzielenia dotacji informację o planowanej liczbie uczniów nie później niż do dnia 30 września roku poprzedzającego rok udzielenia dotacji (art. 80 ust. 2c i art. 90 ust. 2a u.s.o.). Natomiast organ samorządowy zobowiązany jest do udzielenia dotacji niepublicznym szkołom i placówkom oświatowym w przypadku spełnienia przez nie warunków określonych w art. 80 i art. 90 u.s.o. i złożenia odpowiedniego wniosku.

Dotacje z art. 80 i art. 90 u.s.o. orzecznictwo sądów administracyjnych przyjęło określać mianem „dotacji oświatowych”22.

Szczegółowe regulacje dotyczące dotowania zadań oświatowych prowadzonych przez podmioty niepubliczne zawarte są w ustawie o systemie oświaty. W art. 80 i 90 u.s.o. znajdziemy unormowania dotyczące: warunków, jakie musi spełnić podmiot chcący otrzymać dotację; sposobu

\footnotetext{
M. Pilich, Komentarz ..., s. 1014.

Por. wyroki NSA z dnia 1 stycznia 2015 r., II GSK 2252/13; 28 maja 2014 r., II GSK 229/13; 9 marca 2014 r., II GSK 916/13.

22 W. Lachiewicz, Zasady obliczania wysokości dotacji oświatowych [w:] A. Babczuk, A. Talik (red.), Dotacje oświatowe Problemy i wyzwania, Warszawa 2015, s. 55.
} 
określenia wysokości dotacji (obligatoryjnych lub fakultatywnych) liczonych na jednego ucznia (wychowanka, słuchacza, absolwenta); terminów przekazywania dotacji; kwestii związanych z rozliczeniem i kontrolą wykorzystania dotacji przez podmiot dotowany, a także okoliczności przekazywania dotacji w wysokości i terminach innych niż wynikają z podstawowych zapisów ustawowych ${ }^{23}$.

Aktem prawa miejscowego, zgodnie z którym należy ustalić i obliczyć dotację, jest uchwała dotacyjna jednostek samorządu terytorialnego. Organy stanowiące jednostek samorządu terytorialnego podejmują uchwałę dotacyjną na podstawie art. 80 ust. 4 i art. 90 ust. $4^{24}$. Według tych przepisów organ stanowiący jednostki samorządu terytorialnego ustala tryb udzielania i rozliczania dotacji oraz tryb i zakres kontroli prawidłowości ich pobrania i wykorzystywania, uwzględniając w szczególności podstawę obliczania dotacji, zakres danych, które powinny być zawarte we wniosku o udzielenie dotacji i rozliczeniu jej wykorzystania, oraz termin i sposób rozliczenia dotacji.

Uchwała dotacyjna jest badana w trybie nadzorczym przez regionalne izby obrachunkowe (art. 11 ust. 1 pkt 4 ustawy o Regionalnych Izbach Obrachunkowych) ${ }^{25}$.

Przykładowo, uchwałą z dnia 4 października 2012 r., nr 228/XXV/2012 Kolegium RIO, działając na podstawie art. 11 ust. 1 pkt 4, art. 18 ust. 1 pkt 1 ustawy z dnia 7 października 1992 r. o regionalnych izbach obrachunkowych oraz art. 91 ust. 1 i ust. 3 ustawy z dnia 8 marca 1990 r. o samorządzie gminnym stwierdziło nieważność uchwały nr XIX/160/12 podjętej w dniu 31 sierpnia 2012 r. przez Radę Miejską w Łazach, która zmieniła swoją uchwałę z dnia 29 kwietnia 2009 r. nr XXIV/225/09 w sprawie trybu udzielania, rozliczania i kontroli dotacji dla przedszkoli i

23 J. Kotlińska, Podstawy prawne udzielania dotacji przez j.s.t. na zadania oświatowe [w:] A. Babczuk, A. Talik (red.), Dotacje oświatowe Problemy i wyzwania, Warszawa 2015, S. 26.

24 P. Ciszewski, Uchwały organu stanowiq̨cego samorzqdu w zakresie udzielania, rozliczania i kontroli dotacji oświatowej [w:] P. Ciszewski, W. Lachiewicz, B. Jakacka, L. Lipiec-Warzecha, A. Pawlikowska (red.), Dotacje oświatowe, Warszawa 2015, s. 159.

25 Ustawa z dnia 7 października 1992 r. o regionalnych izbach obrachunkowych (Dz.U. z 2012 r. poz. 1113 ze zm.). 
szkół niepublicznych prowadzonych na terenie Gminy Łazy przez podmioty nienależące do sektora finansów publicznych. Zmiana polegała na dokonaniu zróżnicowania stawek dotacji na jednego ucznia ze względu na czas rozpoczęcia działalności oświatowej. W uzasadnieniu zaskarżonej uchwały RIO stwierdziła, że zgodnie z art. 90 ust. 4 u.s.o. organ stanowiący j.s.t. ustala tryb udzielania dotacji, uwzględniając w szczególności podstawę obliczania dotacji. Organ stanowiący uprawniony jest do ustalania stawek dotacji dla poszczególnych rodzajów działalności oświatowej bez możliwości różnicowania stawek dla konkretnych podmiotów otrzymujących dotacje.

Wojewódzki Sąd Administracyjny w Gliwicach (wyrok z dnia 16 lutego 2015 r. I SA/GI 1450/14) podzielił stanowisko organu nadzoru, stwierdzając, że w istotny sposób w części uchwały zmieniającej prawodawca lokalny wykroczył poza granice upoważnienia ustawowego, co musiało skutkować stwierdzeniem nieważności ww. uchwały w tej części. W sytuacji, gdy prawodawca określone kwestie reguluje w akcie ustawowym, ich modyfikacja czy uszczegółowienie przez inny podmiot posiadający uprawnienia do stanowienia prawa, są dopuszczalne wyłącznie w przypadku, gdy delegacja ustawowa wprost na to zezwala. W analizowanym przypadku tak nie było.

Przez tryb udzielania dotacji należy rozumieć m.in. wymagania formalne, jakie powinny zostać określone przez podmiot dotujący. Wymaganiami formalnymi są przykładowo: forma wniosku, sposób jego wypełnienia i załączane dokumenty oraz wskazanie organu, do którego wniosek jest skierowany. Pojęcie rozliczania dotacji oznacza czynności z dziedziny księgowości i rachunkowości o charakterze materialno-technicznym. Natomiast tryb rozliczania oznacza reguły i terminy zgłaszania korekty danych stanowiących podstawę naliczania dotacji ${ }^{26}$. Tryb kontroli wykorzystania dotacji obejmuje ustalenie zasad, na jakich będzie się ona odbywać, sposobu postępowania i procedury przeprowadzania kontroli. Zakres kon-

26 Por. wyrok NSA z dnia 29 listopada 2012 r., II GSK 1609/11. 
troli natomiast dotyczy wskazania granic kontroli i elementów poddawanych kontroli ${ }^{27}$.

W orzecznictwie NSA podkreśla się, że uchwała dotacyjna podjęta przez organ stanowiący jednostki samorządu terytorialnego powinna być zgodna z regulacjami ustawowymi, ponieważ w przypadku przekroczenia upoważnień ustawowych pozostawałaby ona w sprzeczności z art. 94 Konstytucji, w myśl którego stanowienie prawa miejscowego następuje na podstawie i w granicach upoważnień ustawowych. Oznacza to niedopuszczalność wyjścia w akcie prawa miejscowego poza granice poważnienia ustawowego. Za niedopuszczalne należy więc uznać modyfikowanie w uchwałach organów stanowiących j.s.t. regulacji ustawowych, poprzez nakładanie na dotowanie jednostki dodatkowych obowiązków, od których spełnienia zależy uzyskanie dotacji ${ }^{28}$.

\section{Jaki sąd jest właściwy w sprawach o dotacje dla podmiotów prowadzących niepubliczne szkoły i placówki oświatowe?}

Wątpliwości i problemy dotyczą ustalenia właściwości sądu w sporach pomiędzy beneficjentami dotacji prowadzącymi szkoły i placówki niepubliczne a organami j.s.t. o zapłatę dotacji. Spory te najczęściej dotyczą dotacji wypłaconej w zaniżonej kwocie oraz dotacji należnej, lecz niewypłaconej w ogóle. Można mówić, że występuje spór pomiędzy sądami administracyjnymi i powszechnymi odnośnie tego, który sąd powinien orzekać w sprawie tej dotacji. Interpretacja i stosowanie przepisów art. 80 i art. 90 ustawy o systemie oświaty przysparza wiele trudności ${ }^{29}$.

Spór dotyczący właściwości sądu nie został jeszcze w pełni rozstrzygnięty, o czym świadczą zaprezentowane poniżej orzeczenia NSA i SN, które dotyczą spraw pomiędzy j.s.t. a podmiotami uprawnionymi do

\footnotetext{
J. Kotlińska, Podstawy prawne udzielania dotacji przez j.s.t..., s. 34.

28 Por. wyrok NSA z dnia 20 maja 2015, II GSK 719/14; wyrok NSA z dnia 9 września 2014 r., II GSK 388/14.

29 M. Zioło, Dotacja w systemie finansów publicznych. Zarys problematyki [w:] A Babczuk, A. Talik (red.), Dotacje oświatowe Problemy i wyzwania, Warszawa 2015, s. 20.
} 
otrzymywania dotacji zgodnie z art. 90 ustawy o systemie oświaty. Sądy, zarówno WSA, NSA, jak i SN często wydają w tych sprawach różne, choć oparte na tych samych lub podobnych ustaleniach, rozstrzygnięcia.

Stanowisko NSA zaprezentowane w postanowieniu z 3 czerwca 2004 r. (OW 53/04) jest następujące „przepisy zawarte w art. 90 ust. 2, ust. 3 i ust. 4 u.s.o. nie przewidują rozstrzygnięcia spraw dotyczących dotacji w postępowaniu administracyjnym”. Według składu sędziowskiego organ stanowiący (w tym przypadku rada powiatu), który określa tryb udzielenia dotacji, decyduje o formie jej przyznawania, jednak niezależnie od charakteru czynności, w jakiej następuje udzielenie dotacji, nie jest to decyzja administracyjna w rozumieniu k.p.a. Ten pogląd podzielił również skład sędziowski NSA w wyroku z 17 stycznia 2007 r. (II GSK 319/07), przyjmując, że „udzielanie dotacji niepublicznym szkołom i placówkom oświatowym nie następuje w formie decyzji administracyjnych, wydawanych w trybie postępowania administracyjnego, prowadzonego na podstawie k.p.a.”. Natomiast „czynności organów stanowiących j.s.t., podejmowane na podstawie, obowiązującego wówczas art. 90 ust 3a u.s.o., mające na celu ustalenie wysokości dotacji dla placówki niepublicznej oraz przekazanie ustalonej kwoty dotacji, są czynnościami, o których mowa w art. 3 ust. 2 pkt 4 p.p.s.a., tj. czynnościami z zakresu administracji publicznej, niebędącymi decyzjami, dotyczącymi uprawnień lub obowiązków wynikających z przepisów prawa. Na podstawie powołanego przepisu zgodność z prawem takich czynności podlega kontroli sądów administracyjnych”. Czynności organów stanowiących j.s.t. w danym rozstrzygnięciu nie zostały uznane za decyzje administracyjne, lecz za czynności z zakresu administracji publicznej.

NSA w dniu 14 stycznia 2009 r. w składzie siedmiu sędziów wydał postanowienie (w którym odmówił podjęcia uchwały) w sprawie zagadnienia prawnego budzące poważne wątpliwości wyrażone w następującym pytaniu: „Czy obliczenie wysokości i przekazanie dotacji placówce niepublicznej, o jakiej mowa w art. 90 ustawy o systemie oświaty, następujące po podjęciu przez radę powiatu uchwały na podstawie art. 90 u.s.o., stanowią podlegające zaskarżeniu do sądu administracyjnego akty lub czynności wymienione w art. 3 ust. 2 pkt 4 p.p.s.a.”. Według składu 
orzekającego z samej ustawy nie wynika dokładnie wysokość dotacji, ponieważ ustawa określa jedynie przesłanki (podstawy) ustalenia wysokości dotacji. Co więcej, dotacja również w obowiązującym stanie prawnym może być ustalona w wyższej wysokości. Wymaga to zatem konkretyzacji wysokości dotacji w uchwale budżetowej. NSA w uzasadnieniu podkreśla również, że uchwała budżetowa, która jest planem dochodów i wydatków samorządu, nie kreuje bezpośrednio żadnych uprawnień osób trzecich czy zobowiązań wobec osób trzecich. Jeżeli zatem organ stanowiący j.s.t. ustalił tryb udzielania i rozliczania dotacji, przewidując określanie wysokości dotacji w formie umowy, to czynność obliczenia i przekazania każdej z 1/12 części dotacji mogłaby być traktowana wyłącznie jako czynność wykonania zobowiązania przez stronę stosunku obligacyjnego. Natomiast inaczej należałoby oceniać sytuację wówczas, gdyby takiej umowy nie zawarto. Dotacja zostałaby zaś określona jednostronnie przez organ j.s.t. wyłącznie na podstawie zasad sformułowanych w ustawie. Zdaniem sądu kwestie te nie zostały dostatecznie wyjaśnione w postępowaniu sądowoadministracyjnym dlatego zagadnienie prawne budzące poważne wątpliwości przedstawione przez skład orzekający NSA zostało przedstawione przedwcześnie.

W postanowieniu NSA z 12 marca 2013 r. (II GSK 257/13) czynność organu wykonawczego mająca na celu obliczenie wysokości dotacji i jej wypłacenie dla niepublicznej placówki została uznana za czynność z zakresu administracji publicznej w rozumieniu art. 3 ust. 2 pkt 4 p.p.s.a., dotyczącą uprawnień wynikających z przepisów prawa. W uzasadnieniu czytamy: „ustawa o systemie oświaty nie określa bowiem wysokości dotacji, a zatem jej obliczenie jest wykonaniem prawa określonego w art. 90. Ocena zgodności z prawem tego rodzaju czynności stosownie do treści art. 3 ust. 2 pkt 4 p.p.s.a. jako czynności z zakresu administracji publicznej podlega kontroli sądów administracyjnych”.

Takie samo stanowisko co do ustalenia charakteru prawnego omawianych czynności zostało zaprezentowane w postanowieniach NSA z 27 marca 2013 r. (II GSK 322/13) i 15 lipca 2014 r. (II GSK 1634/14).

Należy też przytoczyć zawartą w postanowieniu SN z dnia 7 maja 1999 r. (I CKN 1132/97) następującą tezę: „niedopuszczalna jest droga 
sądowa w sprawie z powództwa niepublicznej szkoły o uprawnieniach szkoły publicznej przeciwko Skarbowi Państwa lub j.s.t. o zapłatę dotacji udzielonej na podstawie art. 90 u.s.o.”. W uzasadnieniu tego orzeczenia argumentuje się, że komentowana regulacja bez żadnych wątpliwości mieści się w sferze prawa finansowego (administracyjnego), będącego ze swej natury częścią składową prawa publicznego, Skarb Państwa zaś lub jednostka samorządu terytorialnego zajmuje w stosunku do podmiotu uprawnionego do otrzymania dotacji pozycję działającego z mocy władzy zwierzchniej, co wyklucza istnienie między stronami stosunku cywilnoprawnego.

Trybunał Konstytucyjny 10 lipca 2000 r. wydał orzeczenie (SK 12/99), w którym wyraził stanowisko, iż między osobami pozostającymi w stałym stosunku cechującym się brakiem równorzędności (np. stosunek służbowy, stosunek między organem administracji reprezentującym państwo a obywatelem) może dojść do ukształtowania więzi, w której podmioty te posiadają równy status. TK podkreślił również, że nie można wykluczyć, iż roszczenie o zapłatę powstałe na tle stosunku administracyjno-prawnego ma charakter cywilnoprawny, a spór dotyczący jego wykonania należy zakwalifikować jako sprawę cywilną.

Na ten wyrok TK powołał się skład sędziowski SN orzekający w sprawie przeciwko Skarbowi Państwa - wojewodzie o zapłatę dotacji (wyrok z dnia 3 stycznia 2007 r., IV CSK 312/06). Chociaż wyrok ten nie dotyczy sporu pomiędzy samorządem a beneficjentem dotacji prowadzącym szkołę niepubliczną, jest on bardzo ważny, ponieważ stanowisko w nim zaprezentowane ukształtowało linię orzeczniczą SN. Sąd uznał, że jeżeli w ustawie nie przewidziano w ogóle właściwości organu administracji lub sądu administracyjnego do orzekania w określonej sprawie, w której powód domaga się ochrony prawnej, to sąd powszechny nie tylko nie może odrzucić pozwu z uwagi na niedopuszczalność drogi sądowej, lecz wprost przeciwnie - ma bezwzględny, konstytucyjny obowiązek rozpoznać sprawę co do istoty.

Kilka miesięcy później SN w postanowieniu z dnia 23 października 2007 r. (III CZP 88/07) podzielił to stanowisko. Ponadto uzasadnił, że roszczenie o dotację na rzecz oznaczonego podmiotu prowadzącego szko- 
łę niepubliczną jest ustalone w ustawie, w art. 90 ustawy o systemie oświaty, co stanowi dostateczną podstawę prawną roszczenia o należną niepublicznej szkole dotację. „Wspomniane przepisy określają bowiem w sposób jasny i bezwarunkowy, kto jest dłużnikiem (właściwa j.s.t.), kto zaś wierzycielem (osoba prowadząca szkołę lub inną placówkę niepubliczną), a także w jakiej wysokości świadczenie się należy i od spełnienia jakich przesłanek wypłacenie dotacji jest uzależnione”.

Jedno z najnowszych orzeczeń SN z dnia 26 marca 2015 r. (V CSK 376/14) potwierdza dotychczasowe rozstrzygnięcia w tej materii. W uzasadnieniu czytamy: „Przepis art. 90 u.s.o. kreuje między jednostkami samorządu terytorialnego właściwymi do wypłaty dotacji, a osobami prowadzącymi niepubliczne placówki oświatowe stosunek prawny odpowiadający cechom zobowiązania w rozumieniu art. 353 ust. 1 k.c., na podstawie którego uprawniony może domagać się części należnej mu dotacji. $\mathrm{W}$ ramach powstającego na tej podstawie stosunku prawnego strony mogą, z ograniczeniami wynikającymi z treści art. 353 z indeksem 1, umówić się co do terminów realizacji wypłaty dotacji. Skutki ich niedotrzymania podlegają ocenie na podstawie przepisów kodeksu cywilnego".

Także w orzecznictwie NSA znaleźć można stanowisko, że stosunki dotyczące dotacji dla podmiotów prowadzących szkoły niepubliczne są stosunkami o charakterze zobowiązaniowym.

W postanowieniu NSA z 26 stycznia 2011 r. (II GSK 98/10), w których rozstrzygane są spory o wysokość dotacji w poszczególnych latach, uznaje się, że czynności organu wykonawczego j.s.t. polegające na wyliczeniu dotacji dla konkretnej placówki oświatowej nie należą do żadnej z form działania administracji publicznej, bowiem przepisy u.s.o. nie przewidują załatwienia spraw dotacji w formie decyzji administracyjnej, postanowienia, bądź jakiegokolwiek innego aktu lub czynności. Według składu orzekającego NSA organ wykonawczy gminy jest zobowiązany, po uprzednim spełnieniu warunków przez beneficjenta, do obliczenia i wypłacenia należnej dotacji osobie uprawnionej. Organ wykonawczy dokonuje tzw. konkretyzacji wysokości dotacji, a ta stricte techniczna czynność o charakterze księgowo-rachunkowym nie kwalifikuje się jako czynność określona przepisem art. 3 ust. 2 pkt 4 p.p.s.a., przez którą ro- 
zumie się konkretną czynność materialno-prawną z zakresu administracji publicznej, podjętą przez organ administracji samorządowej, stanowiącą władcze rozstrzygnięcie organu $\mathrm{w}$ indywidualnej sprawie, dotyczącą stwierdzenia albo uznania uprawnienia lub obowiązku wynikających z przepisów prawa.

Ponadto z art. 90 u.s.o. wynika - czytamy w uzasadnieniu NSA dotyczącym postanowienia z 26 stycznia 2011 r. - że norma ta kreuje pomiędzy Skarbem Państwa lub j.s.t. właściwymi do wypłaty dotacji a osobami prowadzącymi szkoły lub placówki niepubliczne, uprawnionymi do żądania ich otrzymania, stosunek prawny odpowiadający cechom zobowiązania w rozumieniu art. 353 ust. 1 k.c. Zdaniem NSA w przepisach ustawy o systemie oświaty nie przewidziano szczególnego trybu dochodzenia tego rodzaju roszczeń na drodze postępowania administracyjnego, zatem uprawniony może poszukiwać ochrony prawnej tylko przed sądem powszechnym w postępowaniu cywilnym.

Powyższe postanowienie ukształtowało linię orzeczniczą NSA, według której dochodzenie roszczeń o należną, lecz niewypłaconą dotację odbywa się na drodze sądowej w postępowaniu cywilnym, a właściwym do rozpoznania sprawy o takie roszczenie jest sąd powszechny ${ }^{30}$.

\section{Podsumowanie}

Szkoły i placówki niepubliczne oraz szkoły niepubliczne o uprawnieniach szkół publicznych mogą być zakładane i prowadzone przez osoby fizyczne i osoby prawne takie jak: fundacje, stowarzyszenia, spółki kapitałowe prawa handlowego. Procedury ich powstawania zawarte $\mathrm{w}$ ustawie o systemie oświaty przewidują wymóg uzyskania wpisu do ewidencji, a w przypadku szkół niepublicznych o uprawnieniach publicznych również uzyskania zezwolenia właściwego organu jednostki samorządu terytorialnego. Ponadto przepisy ustawy o systemie oświaty umożliwiają przekazanie szkoły publicznej do prowadzenia podmiotom niepublicznym.

30 Por. wyrok NSA z dnia 11 kwietnia 2012 r., II GSK 562/12; postanowienie NSA z dnia 16 października 2012 r., II GSK 1649/12; wyrok NSA z dnia 17 października 2014 r., II GSK 1700/14. 
Niepubliczne szkoły i placówki prowadzone przez stowarzyszenia, fundacje i inne podmioty prywatne są dotowane z budżetu poszczególnych jednostek samorządu terytorialnego. Dotacje dla szkół i placówek niepublicznych prowadzonych przez osoby fizyczne i osoby prawne inne niż j.s.t. służą finansowaniu bieżącej działalności tych jednostek oświatowych. Z tego względu dotacje te mają charakter dotacji podmiotowych. Można też uznać, że charakter podmiotowo-celowy. Również w orzecznictwie przyjmuje się coraz częściej mieszany (podmiotowo-celowy) charakter tych dotacji.

Dotacje dla szkół i placówek niepublicznych są obligatoryjnym świadczeniem z budżetów jednostek samorządu terytorialnego, o czym stanowi art. 90 ustawy o systemie oświaty. Jednak często dochodzi do sporów pomiędzy uprawnionymi do dotacji podmiotami a poszczególnymi j.s.t. Spory dotyczące dotacji dla niepublicznych szkół i placówek oświatowych rozstrzygają sądy zarówno administracyjne, jak i powszechne. Sądy administracyjne badają uchwały j.s.t. dotyczące dotacji. Rozstrzygnięcia nadzorcze RIO są zaskarżane do sądu administracyjnego.

Z orzecznictwa SN i NSA wynika jednak, że dochodzenie roszczeń o należną, lecz niewypłaconą dotację oświatową dla konkretnego beneficjenta (np. stowarzyszenia) powinno odbywać się na drodze sądowej w postępowaniu cywilnym. Stosunek prawny dotyczący dotacji oświatowych przekazywanych przez j.s.t. dla podmiotów niepublicznych ma charakter stosunku zobowiązaniowego (cywilnoprawnego).

\section{Bibliografia:}

Borodo A., Samorzqd terytorialny System prawnofinansowy, Wydawnictwo LexisNexis, Warszawa 2012.

Ciszewski P., Uchwały organu stanowiq̨cego samorzq̨u w zakresie udzielania, rozliczania i kontroli dotacji oświatowej [w:] P. Ciszewski, W. Lachiewicz, B. Jakacka, L. Lipiec-Warzecha, A. Pawlikowska (red.), Dotacje oświatowe, Wydawnictwo C.H. Beck, Warszawa 2015.

Kotlińska J., Podstawy prawne udzielania dotacji przez j.s.t. na zadania oświatowe [w:] A. Babczuk, A. Talik (red.), Dotacje oświatowe Problemy i wyzwania, Wydawnictwo Ośrodek Rozwoju Edukacji, Warszawa 2015. 
Kurzyna-Chmiel D., Oświata jako zadanie publiczne, Wydawnictwo Wolters Kluwer SA, Warszawa 2013.

Lachiewicz W., Zasady obliczania wysokości dotacji oświatowych [w:] A. Babczuk, A. Talik (red.), Dotacje oświatowe Problemy i wyzwania, Wydawnictwo Ośrodek Rozwoju Edukacji, Warszawa 2015.

Ofiarski Z., Subwencje i dotacje jednostek samorzq̨du terytorialnego, Wydawnictwo Difin, Warszawa 2002.

Ostrowska A., Udzielanie dotacji niepublicznym jednostkom oświaty - samorzqdowa powinność czy samorzq̨owe władztwo finansowe? [w:] A. Borodo (red.), Dotacje i subwencje w systemie finansowym samorzqdu terytorialnego, Wydawnictwo TNOiK, Toruń 2013.

Ostrowska A., Jakie sq istota i rodzaje dotacji podmiotowych udzielanych z budżetu j.s.t.? [w:] C. Kosikowski, J.M. Salachna (red.), Finanse samorzq̨dowe. 580 pytań i odpowiedzi, Wydawnictwo Wolters Kluwer SA, Warszawa 2012.

Pilich M., Komentarz do ustawy o systemie oświaty, Wydawnictwo Wolters Kluwer SA, Warszawa 2015.

Zioło M., Dotacja w systemie finansów publicznych. Zarys problematyki [w:] A Babczuk, A. Talik (red.), Dotacje oświatowe Problemy i wyzwania, Wydawnictwo Ośrodek Rozwoju Edukacji, Warszawa 2015. 